\title{
EL DERECHO DE DESISTIMIENTO DEL CONSUMIDOR EN EL ORDENAMIENTO JURÍDICO ESPAÑOL. SU DELIMITACIÓN RESPECTO DE OTRAS FORMAS DE INEFICACIA CONTRACTUAL
}

\section{The consumer withdrawal right in the} Spanish legal system. Its delimitation regarding another contractual inefficiency

Henrry Sosa OláN* Universidad de Salamanca

Salamanca, España

RESUMEN: El derecho de desistimiento del consumidor aparece como un nuevo derecho en las políticas legislativas de la Unión Europea. A pesar de ser una figura asistemática y fragmentaria que se encuentra regulada en diversas leyes, cuenta con unas características propias, lo cual la distingue de otra formas de ineficacia contractual, como la nulidad, anulabilidad, rescisión, etc. Asimismo, con la entrada en vigor de la Ley española $n^{\circ} 3 / 2014$, por la que se modifica el Texto Refundido de la Ley General para la Defensa de los Consumidores y Usuarios de 2007, se unifica y armoniza el régimen jurídico del derecho de desistimiento, tanto en materia de

Doctor en Derecho por la Universidad de Salamanca, España. Correo electrónico: $<$ henrrypleyares@hotmail.com>.

Artículo recibido el 30 de mayo de 2016 y aprobado para publicación el 2 de noviembre de 2016. 
contratación a distancia como en materia de contratos celebrados fuera del establecimiento mercantil.

PALABRAS CLAVE: Derecho de desistimiento, consumidor, directiva, contrato, ineficacia contractual

ABSTRACT: The consumer withdrawal appears as a new right within politics of the European Union. Despite being an unsystematic and fragmentary figure that is regulated in different statutes, it has its own characteristics, which, it distinguish it from others forms of contractual inefficiency, such as the nullity, voidability, rescission, etc. Moreover, with the entry into force of the Spanish Act 3/2014, that modify the Consumers and Users Protection General Act of 2007, the legal regime of the consumer withdrawal right is unified and harmonized in matters of distance contracts and contacts concluded out of business establishments.

KEYWORDS: Right of withdrawal, consumer, directive, contract, contractual inefficiency

\section{INTRODUCCIÓN}

A través del paso de los años nos queda clara la delimitación jurídica del derecho de desistimiento del consumidor, por lo tanto, en la actualidad, no cabe confundirlo con otros tipos de ineficacia contractual (resolución, rescisión, anulabilidad, entre otras), ya que posee unos rasgos y caracteres propios.

Asimismo, el desistimiento del consumidor se configura como un derecho nuevo, el cual surge de las políticas legislativas de la Unión Europea. No obstante, cabe aclarar que este derecho no se puede separar de la teoría de obligaciones y contratos, debido a que sus efectos tienen como consecuencia la restitución recíproca de las cosas (artículos 1.303-1.308 del Código Civil, en adelante CC). Sin embargo, estos varían, dependiendo ante qué tipo de contratos nos encontremos. Si el desistimiento recae sobre bienes los efectos que produce son ex tunc, es decir, se pretende volver al estado de la cuestión, tal y como se encontraba desde el inicio. En cambio, si sus efectos recaen sobre servicios, el efecto es ex nunc, por lo tanto, no existe retroactividad al no poder volver a la situación inicial. 
El presente trabajo se encuentra dividido en dos partes. En la primera analizamos los típicos supuestos de ineficacia contractual regulados en el CC como la nulidad, la anulabilidad, la rescisión, la revocación y la resolución. Luego, en la segunda parte, se examina el concepto y las características del derecho de desistimiento del consumidor.

Debemos aclarar que, en España, el artículo $3^{\circ}$ del Texto Refundido de la Ley General para la Defensa de los Consumidores y Usuarios (en adelante TRLGDCU), modificado por la Ley $\mathrm{n}^{\circ} 3 / 2014$, define al consumidor de la siguiente manera: "A efectos de esta norma y sin perjuicio de lo dispuesto expresamente en sus libros tercero y cuarto, son consumidores o usuarios las personas físicas que actúen con un propósito ajeno a su actividad comercial, empresarial, oficio o profesión.

Son también consumidores a efectos de esta norma las personas jurídicas y las entidades sin personalidad jurídica que actúen sin ánimo de lucro en un ámbito ajeno a una actividad comercial o empresarial".

Cabe señalar que el concepto comentado contiene una peculiaridad respecto de la Directiva de los Derechos de los Consumidores (en adelante DDC) de año 2011, pues esta última sólo admite que la persona física sea consumidor. ${ }^{1}$ Sin embargo, a pesar de que el artículo 3 del TRLGDCU incluye a las personas jurídicas, en nada contraviene a la normativa comunitaria, debido a que hace la aclaración que serán consideradas consumidores siempre y cuando actúen sin fines de lucro, tal y como lo ha dejado claro el Tribunal de Justicia de las Comunidades Europeas en sus diversas sentencias, en donde ha excluido a las personas jurídicas del régimen jurídico de protección al consumidor que realizan actividades con fines de lucro. ${ }^{2}$

Lo opuesto a consumidor sería un empresario, el cual es definido en el artículo 4 del TRLGDCU, modificado por Ley $n^{\circ} 3 / 2014$, en los siguientes términos: "A efectos de lo dispuesto en esta norma, se considera empresario a toda persona física o jurídica, ya sea privada o pública, que actúe

Artículo 2.1 de la DDC: “Toda persona física que, en contratos regulados por la presente Directiva, actúe con un propósito ajeno a su actividad comercial, empresa, oficio o profesión".

2 Vid. Al respecto las siguientes sentencias del Tribunal de Justicia de las Comunidades Europeas: Gruber contra Bay Wa AG (2005, asunto C-464/01), Engler contra Janus Versand $\mathrm{GmbH}$ (2005, asunto C-27/02), Benincasa contra Dentalkit (1997, asunto C-269/95), Shearson Lehman Hutton contra TVB Treuhandgesellschaft für Vermögensverwaltung und Beteiligungen $\mathrm{mbH}$ (1993, asunto C-89/91); entre otras. 
directamente o a través de otra persona en su nombre o siguiendo sus instrucciones, con un propósito relacionado con su actividad comercial, empresarial, oficio o profesión".

Por otra parte cabe aclarar que la Ley $n^{\circ} 3 / 2014$, por la que se modifica el TRLGDCU, unifica y armoniza el régimen jurídico del derecho de desistimiento, tanto en materia de contratación a distancia como en materia de contratos celebrados fuera del establecimiento mercantil, razón por la cual se modifica el Título II del TRLGDCU de 2007, eliminándose el Título V, cuya denominación y contenido pasa ahora al Título IV, en cuyo Capítulo III se regula el derecho de desistimiento en materia de contratos a distancia y contratos celebrados fuera del establecimiento mercantil (artículos 102 a 108 del TRLGDCU). Por lo tanto, se unifican los plazos para desistir, las sanciones civiles, las obligaciones del consumidor y vendedor, los efectos del derecho de desistimiento en los contratos vinculados, así como también se facilita su ejercicio con la introducción de un formulario de desistimiento previsto en el Anexo B. ${ }^{3}$

Por último, cabe aclarar que, a pesar de que el derecho de desistimiento tiene diferentes fundamentos ${ }^{4}$, cuenta con un régimen jurídico propio (artículos 68 a 79 del TRLGDCU) y características propias, tal y como se examina en el presente trabajo.

\section{LOS SUPUESTOS DE INEFICACIA CONTRACTUAL}

Dentro del presente epígrafe, se analiza de manera general las figuras típicas de ineficacia contractual (nulidad, anulabilidad, rescisión, resolución y revocación) con el fin de distinguirlas del derecho de desistimiento otorgado al consumidor en ciertos contratos, teniendo en cuenta, además, que éste puede ser compatible con aquéllas en muchos casos.

3 Vid. Más sobre el derecho de desistimiento en materia de contratación a distancia en DíAz (2014).

$4 \quad$ Vid. El punto 37 de la DDC cuando aclara: "Dado que en las ventas a distancia el consumidor no puede ver los bienes antes de celebrar el contrato, debe disponer de un derecho de desistimiento. Por el mismo motivo, el consumidor debe estar autorizado a probar e inspeccionar los bienes que ha comprado en la medida suficiente que le permita determinar la naturaleza, las características y el buen funcionamiento de los bienes. En cuanto a los contratos celebrados fuera del establecimiento, debe permitirse al consumidor que ejerza un derecho de desistimiento, ya que puede haber un elemento sorpresa o presión psicológica. El ejercicio del derecho de desistimiento debe poner fin a la obligación de las partes contratantes de ejecutar el contrato". 
Los términos "invalidez" e "ineficacia" han sido diferenciados por la doctrina. Un contrato será inválido si no cumple con los requisitos esenciales que la ley exige, como consentimiento, objeto y causa (artículo 1.261 del CC). En cambio, estaríamos ante un contrato ineficaz cuando siendo válido (reúne los requisitos establecidos por la ley), sin embargo, por diversos motivos, no va a producir efectos. ${ }^{5}$ No obstante, tal y como señala Díez-PıCAZO, "la terminología no es uniforme (...) Los textos hablan de actos o de negocios inútiles, viciosos, imperfectos, etc". ${ }^{6}$

Además como señala Márquez González: "Es confuso el panorama que la doctrina presenta cuando se intenta estudiar el sistema de las nulidades o de las ineficacias. Y es que el problema surge precisamente a partir de la propia denominación que se confiere a la materia misma y a los elementos que conforman el problema en estudio. Así, cuando se trata por ejemplo del fenómeno en general, se habla lo mismo de ineficacia que de nulidad, de invalidez y hasta de irregularidad o anormalidad. Cuando de las especies afectadas del grado más alto de nulidad se trata, se habla entonces de actos nulos en forma absoluta, incompletos, inacabados, irrelevantes, inútiles, estériles, nulos de pleno Derecho y naturalmente, inexistentes, denominación esta última que, desde luego, no se encuentra libre de paradojas. Algunos distinguen luego la inexistencia absoluta, material o de hecho, de aquella otra relativa, racional o jurídica $(\ldots)^{\prime \prime} .7$

A pesar de no haber unanimidad dentro de la doctrina, en lo referente a los términos ineficacia e invalidez, es preciso diferenciarlos. Dentro de la invalidez, nos encontraríamos con las figuras jurídicas de nulidad y anulabilidad, las cuales tienen como fin evitar cualquier tipo de patología que afecte a los elementos esenciales del contrato. En cambio, la ineficacia, en sentido estricto, incluye los defectos o carencias que afectan al contrato de manera

\footnotetext{
De Castro (2008) p. 463.

Díez-Picazo (2007) p. 556.

MÁrQueZ (2008) p. 3.
} 
extrínseca; de este modo, encontramos supuestos de ineficacia contractual como la revocación, rescisión, desistimiento unilateral, resolución ${ }^{8}$, etc. ${ }^{9}$

Por otro lado, es preciso señalar que no existe un criterio uniforme por lo que respecta a la clasificación de los distintos supuestos de ineficacia contractual, debido a que no existe una categoría de orden lógico dentro del ordenamiento jurídico $^{10}$, por lo tanto, acudiremos a la ayuda de la doctrina, la cual se ha esforzado por construir una clasificación.

\section{La nulidad}

La nulidad del contrato, como supuesto de ineficacia contractual, tiene como fin principal salvaguardar la defensa de intereses generales o del orden público, razón por la cual el juez puede declararla de oficio, siendo imprescriptible, debido a que está abierta a cualquier persona con interés legítimo ${ }^{11}$ (artículo 1.261 y siguientes del CC). Asimismo una vez ejercida la acción de nulidad, se deja sin efecto el contrato y, en su consecuencia, procede la devolución de prestaciones, siendo la sanción más grave ante la falta o afectación de los elementos esenciales del propio contrato o contravención del ordenamiento jurídico.

A continuación citamos algunos ejemplos de nulidad absoluta, entre los que encontramos: La carencia absoluta o inexistencia de los elementos esenciales del contrato; el incumplimiento de cualquiera de los requisitos del objeto del contrato; que la causa fuera contraria a Derecho; el incumplimiento de un requisito sustancial del contrato; y que el contrato celebrado fuera en contra de las normas imperativas a la normal y al orden público. ${ }^{12}$

8 En palabras de PARRA (1997) p. 155; la recisión, la revocación, resolución y desistimiento son: “- La rescisión, como es sabido, se refiere a contratos válidamente celebrados pero que, produciendo perjuicio a una de las partes o a un tercero pueden ser declarados ineficaces a solicitud del perjudicado (arts. 1.290 a 1.299 CC). - La revocación es causa sobrevenida de ineficacia de un negocio otorgado válidamente por voluntad de su otorgante, y se reserva para los negocios jurídicos unilaterales (testamento) o los gratuitos (donación). - La resolución es una facultad reconocida legalmente como remedio para la parte de una relación contractual sinalagmática frente al incumplimiento (art.1.124 CC). - El desistimiento es la facultad atribuida a una de las partes de una relación obligatoria de poner fin a la misma por su libre determinación".

9 Cfr. Lasarte (2010) pp. 134-135.

10 Cfr. Díez-Picazo y Gullón (2002) p. 102.

11 Cfr. Quicios (2009) p. 1218.

12 Vid. Lasarte (2010) pp. 135 y 136. 
La trascendencia de la nulidad tiene un efecto general, es decir, erga omnes, por lo tanto las personas a las que afecta este tipo de ineficacia contractual no pueden invocar la protección jurídica de la ley para convalidar el contrato, pues la nulidad trae consigo misma una cadena de nulidades. ${ }^{13}$ La acción de legitimación para reclamar la nulidad corresponde a cualquier persona que ostente un interés legítimo y no está sometida a ningún plazo de ejercicio, considerándose una acción imprescriptible. ${ }^{14}$

Como podemos observar, la nulidad como ineficacia contractual no tiene nada que ver con el derecho de desistimiento del consumidor, pues al momento de ejercer el consumidor el derecho que le asiste, el contrato tiene plena eficacia jurídica, dependiendo de la sola voluntad de dicho consumidor su decaimiento o ineficacia, tal y como veremos más adelante. Lo cierto es que la diferencia entre desistimiento y nulidad contractual no plantea mayores problemas, debido a que el derecho de desistimiento presupone la existencia de un contrato válido y tiene características propias que lo alejan de la nulidad, como es el simple hecho de no necesitar fundamento ninguno para su ejecución y concederse sólo a una de las partes (el consumidor), bien de forma legal, bien de forma contractual.

Debe resaltarse, que será nula la cláusula que impida ejercer el derecho de desistimiento al consumidor, debido a que el empresario tiene la obligación de cumplir con ciertos deberes de información que le impone la ley. Esto con la finalidad de que el consumidor emita un consentimiento informado. ${ }^{15}$ Además, corresponde al empresario la carga de la prueba, en lo tocante al cumplimento de los deberes de información y documentación (artículo 69.2 del TRLGDCU). Por otra parte, es importante mencionar que la falta del ejercicio del derecho de desistimiento en el plazo fijado no será obstáculo para el posterior ejercicio de las acciones de nulidad o resolución del contrato cuando procedan conforme a Derecho (artículo 78 del TRLGDCU). Como podemos ver, el derecho de desistimiento es acumulativo con otras acciones previstas en la normativa, razón por la cual, como señala García Vicente: "(...) la remisión a las acciones de nulidad o resolución se refiere indistintamente a las contempladas en las normas especiales (sea o no el Texto Refundido) y en el Derecho común de contratos, no impide el ejercicio de otras no mencionadas específicamente (las acciones indemnizatorias de cumplimiento, $\mathrm{u}$ otras) (...)". Además, "(...) no significa que el consumidor no pueda, desde la

\footnotetext{
13 Vid. De CAStro (2008) p. 477.

14 Vid. Díez-Picazo (2007) p. 578.

15 Cfr. Beluche (2009a) p. 58.
} 
celebración del contrato y todavía en vigor el derecho a desistir, emprender cualquier otra acción $(\ldots)^{\prime \prime} .^{16}$

\section{La anulabilidad}

La anulabilidad recae sobre aquellos contratos que, reuniendo los requisitos del artículo 1.261 del CC, Ileven aparejados vicios que los invalidan de acuerdo a la ley. El ordenamiento civil Ilama a estos vicios, vicios del consentimiento, entre los que encontramos, el error, dolo, violencia e intimidación. ${ }^{17}$ A diferencia de la nulidad de pleno Derecho, la anulabilidad del contrato como forma de ineficacia contractual se da a instancia de parte, por lo cual, sólo la parte afectada la puede invocar. Con este régimen se busca limitar la legitimación para poder ejercerla, es decir, se utiliza la "anulabilidad como vía para huir de la nulidad, como una no nulidad. ${ }^{18}$ No es necesaria la existencia de una lesión, pues de ésta se encarga la figura de la rescisión.

Para Díez-Picazo, son fundamentalmente cuatro los motivos que traen consigo la anulación de los contratos contemplada en el CC:

i) La falta de una plena capacidad de obrar. Son anulables los contratos llevados a cabo por los incapaces de obrar o por las personas que poseen una capacidad de obrar limitada, así como aquellos en que no se hayan reunido los suplementos o complementos de capacidad necesarios;

ii) La existencia de los llamados "vicios de la voluntad". Por esta razón son anulables los contratos que hayan sido celebrados con error esencial excusable, dolo causante, intimidación y miedo grave;

iii) La falta de consentimiento del otro consorte, cuando sea necesario de acuerdo con el régimen jurídico de la sociedad conyugal, para los actos realizados por uno de los cónyuges (cfr., artículo 1.322 párrafo 1, frente al párrafo

16 García (2009) pp. 875 y 876.

17 Cfr. Quicios (2009) pp. 1255 y 1256. Para esta autora, de declararse un contrato anulable, "habría que predicar de él los tres caracteres esenciales que definen esta ineficacia: la legitimación activa se limita a los sujetos protegidos por la norma vulnerada, la acción está limitada temporalmente y el contrato puede convalidarse. $\mathrm{O}$ a la inversa: si se entiende más adecuado este régimen jurídico de ineficacia para sancionar una invalidez contractual, coherentemente habría que calificar el contrato celebrado anulable".

18 Pasquau (1997) p. 95. 
2, que declara nulos los actos a título gratuito realizados por un cónyuge sin el consentimiento del otro $)^{19} ; y$

iv) La falsedad en la causa, contemplada en el artículo 1.301 CC, es considerado un supuesto de anulabilidad. Sin embargo, tal y como señala la doctrina, tal concepto ha generado dudas interpretativas, sobre todo en materia de contratos simulados, debido a que se duda que pudieran estar sujetos al plazo de prescripción/caducidad de 4 años (artículo $1.302 \mathrm{CC}$ ). ${ }^{20}$ Es importante mencionar, que, a diferencia de la falsedad en la causa que provoca la nulidad relativa, la "expresión de causa falsa" contemplada en el artículo 1.276 CC origina la nulidad absoluta por ir en contra de las normas imperativas y prohibitivas (artículo 3 y 6 CC), razón por la cual el contrato no produce efecto legal alguno.

El plazo para el ejercicio de la anulación del contrato es de cuatro años $^{21}$, de acuerdo con lo estipulado con el artículo 1.302 CC. El ejercicio de la acción de anulación del contrato compete también a los obligados subsidiariamente (artículo 1.302 del CC) así como a los herederos en caso de fallecimiento de la persona legitimada para realizarla. ${ }^{22}$

La figura de la anulabilidad del contrato tampoco tiene nada que ver con el derecho de desistimiento del consumidor. El derecho de desistimiento del consumidor no encuentra su fundamento en la falta de una plena capacidad de obrar, como tampoco en la existencia de los llamados vicios del consentimiento, ni en la falta de consentimiento de una de las partes. El consumidor puede desistir del contrato sin alegar causa alguna. Además, el plazo que se le concede para desistir es breve, se da por la sola declaración del consumidor ${ }^{23}$,

19 Díez-Picazo y Gullón (2002) p. 595.

20 Vid. Grimalt (2008) pp. 10 y 11 , nota 22.

21 Vid. Quicios (2009) p. 1276, para esta autora hay que distinguir el dies a quo de la anulabilidad del contrato, si "la demanda basada en el error o el dolo (o la falsedad de la causa, que no es más que un tipo de error) ha de interponerse en los cuatro años posteriores a la consumación del contrato; la demanda basada en la violencia o la intimidación, en los cuatro años posteriores a la cesación del vicio".

22 Cfr. Díez-Picazo y Gullón (2002) p. 596.

23 Vid. Jerez (2011) p. 125. Cuando aclara que la anulabilidad se distingue del derecho de desistimiento que las Directivas europeas han impulsado en nuestras leyes (right to renounce o right to witdrawal), porque el derecho de desistimiento legitima al contratante favorecido para abandonar el contrato dentro de un periodo de tiempo determinado, que suele ser breve (por ejemplo, una semana) sin necesidad de alegar razón alguna, mientras 
es irrenunciable, su ejercicio determina la extinción del contrato de consumo concertado y válido, y puede tener su origen legal o contractualmente.

\section{La rescisión}

La rescisión como forma de ineficacia contractual afecta a contratos válidos (artículos 1.290 a 1.299 del CC), cuando no hay otro medio para resarcir a la parte perjudicada por el daño que le ha ocasionado dicho contrato. ${ }^{24} \mathrm{El}$ plazo para ejercitar la rescisión del contrato es de cuatro años (artículo 1.299 del CC), siendo dicho plazo de caducidad. Debemos aclarar que dependiendo del tipo de rescisión ante el que nos encontremos, el dies a quo para interponerla varía. ${ }^{25}$

Para Federico De Castro, tres son las características que distinguen a la rescisión de otras figuras de ineficacia contractual:

i) Priva de eficacia a un negocio válido.

ii) Es subsidiaria, es decir se tienen que agotar antes otros recursos.

iii) Se trata de evitar un perjuicio de tipo económico y, por lo tanto, ha de quedar acreditado dicho daño. ${ }^{26}$ Este último elemento es el que caracteriza a la rescisión frente a las otras formas de ineficacia contractual, ya que "en toda rescisión contractual subyace el daño económico como justificante de la ruptura del contrato, aunque sea directo en algunos casos e indirecto en otros" ${ }^{\prime 27}$

La rescisión la puede interponer el perjudicado, que puede ser cualquiera de las partes o un tercero dependiendo del tipo de rescisión, ya sea por

que el ejercicio de la facultad de anular el contrato necesariamente ha de estar fundado en una causa de nulidad relativa legalmente prevista que debe alegarse para su ejercicio.

24 Vid. Díez-Picazo y Gullón (2002) pp. 596 y 112.

25 Vid. Quicios (2009) p. 1287, cuando aclara: "si estamos a los rasgos distintivos de la acción de rescisión, los otros supuestos de rescisión especialmente determinados por la Ley (art. 1.291.5. del CC) no pueden ser todos aquellos que, con dicho nombre, van apareciendo a lo largo del articulado del Código Civil o en la Ley concursal) (...) Téngase presente que la acción de rescisión es subsidiaria (art. 1.294 del CC), está sujeta a un plazo de caducidad, por tanto no susceptible de interrupción, de cuatro años (art. 1.299 del CC), y obliga a la restitución de las prestaciones intercambiadas (art. 1.295 del CC)".

26 De Castro (2008) p. 523.

27 Díaz (2008) pp. 1352 y 1353. 
lesión o fraude. Lo anterior se deduce de la interpretación de los artículos $1.290,1.291 .5$ y 1.293 del CC.

La confusión entre los términos "desistimiento" y "rescisión" tiene su origen en la hoy derogada Directiva 85/577/CEE, de contratos celebrados fuera de establecimientos mercantiles, la cual, en su Exposición de Motivos refería a un mal Ilamado "derecho de rescisión" confundiéndolo con el "desistimiento unilateral" otorgado al consumidor para dejar sin efecto el contrato. Lo anterior se debe a la falta de rigor técnico al momento de aprobar el legislador europeo las directivas ${ }^{28}$, las cuales no tienen como fin establecer categorías jurídicas. Esta falta de precisión terminológica ha sido corregida por el legislador europeo al promulgar la DDC de año 2011.

La rescisión como forma de ineficacia contractual tampoco se asemeja al derecho de desistimiento que la ley concede al consumidor: si bien es cierto que en ambos casos se priva de eficacia a un negocio válido, no lo es menos que en la rescisión la presencia de justa causa (como lo es el perjuicio económico) es indispensable para su ejercicio. En cambio, el derecho de desistimiento se ejercita sin necesidad de alegar causa alguna (artículo 68.1 del TRLGDCU ${ }^{29}$, sin que exista ningún tipo lesión económica. Por lo tanto, no se trata de ningún remedio (mucho menos, uno subsidiario) de situación alguna de fraude o de lesión; de hecho, aunque éstos se dieran, ni siquiera sería necesaria su alegación para que triunfara la pretensión del consumidor. Hay, además, otras diferencias esenciales: una de las partes, el vendedor, ha de respetar el ejercicio del derecho de desistimiento cuando lo haya pactado, por ejemplo, en los contratos presenciales (artículo 79 del TRLGDCU) o en los casos previstos por la ley. Además, el empresario, para el caso de desistimiento, tiene la obligación de cumplir con ciertos deberes accesorios, como el facilitamiento de un documento de desistimiento (artículo 69 del TRLGDCU).

$28 \quad$ Vid. Álvarez (2000) p. 169.

29 En el mismo sentido se manifiesta la DDC en su artículo 9.1: "Salvo en caso de aplicación de las excepciones establecidas en el artículo 16, el consumidor dispondrá de un periodo de 14 días para desistir de un contrato a distancia o celebrado fuera de establecimiento, sin indicar el motivo y sin incurrir en ningún coste distinto de los previstos en el artículo $13 \mathrm{~m}$ ) apartado 2, y en el artículo 14". También el artículo 14.1 de la Directiva de crédito al consumo del año 2008: "El consumidor dispondrá de un plazo de 14 días civiles para desistir del contrato de crédito sin indicar el motivo". 


\section{La revocación}

La revocación ${ }^{30}$ como forma de ineficacia se da en actos jurídicos unilaterales que dejan sin efecto la voluntad inicialmente dada, como pueden ser el testamento y la donación. ${ }^{31}$ La revocación es la "potestad legal concedida por la ley a una de las partes para extinguir el contrato unilateralmente en los casos donde expresamente se autorice tal proceder". ${ }^{32}$ Así también, la doctrina ha puesto de manifiesto que el derecho de revocación se compatibiliza con las normas de vicios de la voluntad con el fin de proteger la formación de la voluntad contractual. No obstante, la figura de la revocación "no es una figura de perfiles unitarios en nuestro $\mathrm{CC}$, se atribuye por diversas razones y para negocios jurídicos dispares entre sí". ${ }^{33}$

En sentido amplio o vulgar se dice a veces que el desistimiento supone una revocación de su voluntad por parte del consumidor, tal y como aclaró en su momento García Vicente refiriéndose al artículo 5 de la ya derogada Ley $n^{\circ}$ 26/1991, de contratos celebrados fuera de establecimientos mercantiles. ${ }^{34}$

No obstante, parte de la doctrina señala que esta figura es la que más se asemeja al derecho de desistimiento en cuanto a sus características, debido a que el legislador español no ha delimitado las fronteras entre ambas figuras, teniendo un carácter homogéneo y no siendo de perfiles únicos. ${ }^{35}$ Sin embar-

$30 \quad$ Vid. KLEIN (1997) pp. 115 y 116: "Con más precisión, se ha calificado la revocación como un reflejo de un iusponitendi, es decir, de una facultad de retractar o retirar una voluntad ya manifestada y eficaz; se caracteriza por ser un negocio jurídico unilateral, que debe provenir del autor del propio acto que se quiere retirar, es ejercitable extrajudicialmente, no suele estar condicionado a causas o circunstancias sobrevenidas, pero, sobre todo, está reservado a desplegar su eficacia frente a otros negocios unilaterales $y$, por regla general, queda excluido de los contratos".

31 Vid. Mayor Del Horo (2010) pp. 106 y 107.

32 Rodríguez (1991) p. 118.

33 BeCKer y García (1996) p. 915, nota 15.

34 Cfr. García (1997) pp. 89 y 90, refiriéndose al artículo 5 de la ya derogada Ley n 26/1991 que regulaba el derecho de revocación que en realidad era un derecho de desistimiento del consumidor.

35 Ídem., p. 113: “(...) Hubiera sido igualmente correcto (en razón de su función extintiva de una relación obligatoria ya existente y su modo de ejercicio a través de una declaración de voluntad unilateral recepticia) que el legislador lo hubiera denominado "derecho de desistimiento"; en realidad, desistimiento y revocación son términos plenamente intercambiables desde un punto de vista dogmático, porque las fronteras entre estas figuras son borrosas y el legislador no ha tenido especial cuidado en distinguirlas. Tantas son sus 
go, como bien apunta Álvarez Moreno, existen tres características para delimitar el campo de aplicación de la revocación y el desistimiento en cuanto a su ámbito de actuación:

La primera consiste en que la revocación sólo se da en actos jurídicos unilaterales como el testamento y la donación, cosa que no ocurre en el desistimiento, el cual lo concede la ley de manera unilateral o bilateral o, por pacto de las partes, atendiendo al principio de autonomía de la voluntad.

La segunda característica tiene que ver con su fundamento, debido a que la revocación sólo se da ante causas concretas y previstas por la ley. Además se debe alegar una causa específica para que produzca efectos sobre el negocio. Lo anterior no ocurre con el derecho de desistimiento, ya que éste se otorga al consumidor sin necesidad de alegar causa alguna (ad nutum).

Por último, en la revocación la ley concede un amplio plazo para su ejercicio, lo cual no se da en el derecho de desistimiento del consumidor, que se concede por un breve periodo de tiempo (14, 20 ó 30 días). ${ }^{36}$

Otro argumento más para no confundir la figura objeto de nuestro estudio con la figura de la revocación, es en el sentido de que la denominación "desistimiento" en el ámbito de consumo tiene como fin proteger al consumidor, dando un equilibrio a la relación contractual cuando una parte es considerada débil. En cambio, en la revocación se atiende generalmente a los intereses del dueño del negocio (el donante o testador) o terceros afectados. No es, en definitiva, un instrumento legislativo de protección del contratante caracterizado como "débil" (el consumidor) frente a su contraparte en el negocio (empresario).

\section{La resolución}

A diferencia del derecho de desistimiento del consumidor, que se atribuye a una sola de las partes en una relación sinalagmática, la resolución se atribuye a ambos contratantes (artículo 1.124 del CC) ${ }^{37}$, y previo incumplimiento de una de las partes, ya sea debido a la voluntad propia o a un hecho obstativo del cumplimiento.

afinidades que si difícilmente podemos apuntar algo más que una simple tendencia en orden a su configuración técnica más precisa, parece imposible señalar esa tendencia en la razón de su atribución". En la misma línea MárQuez (2008) pp. 482 y 483.

36 Cfr. Álvarez (2000) pp. 173 y 174.

37 Vid., por todos RodríGuez (1991) p. 111. 
La resolución es una ineficacia debido a que no conlleva un defecto en el momento del nacimiento del contrato. Halla su fundamento en diversos casos, que incluyen la libre voluntad de una de las partes o de las dos, y los supuestos de hecho permitidos por la ley para dar por finalizado un contrato. ${ }^{38}$

Sus características son las siguientes:

i) En la resolución es el acreedor el que tiene la libertad de pedir que finalice el contrato por no interesarle continuar manteniendo relaciones jurídicas con quien ha incumplido. ${ }^{39}$

ii) Tiene efectos retroactivos por lo cual las partes tienen la obligación de restituirse las prestaciones; $y$,

iii) La justa causa que tiene por objeto la extinción del contrato, la cual encuentra su fundamento en circunstancias personales de las partes, o a eventos relativos al objeto contractual. ${ }^{40}$

Para que una de la partes pueda resolver un contrato se deben dar ciertos requisitos. En un contrato existen obligaciones principales y accesorias; la jurisprudencia ha manifestado que la falta de cumplimiento de estas últimas no es causa de resolución del contrato. Además, el incumplimiento ha de ser grave, lo cual ocurre cuando el cumplimiento de la obligación es irrealizable, ya sea por haber desaparecido el objeto del contrato o porque ocurra un hecho obstativo que lo impida. Se debe tener en cuenta que es irrelevante la causa del incumplimiento, es decir, la resolución del contrato puede solicitarse al demandado por razones imputables a su voluntad (dolo o negligencia) o por hechos ajenos a su voluntad (imposibilidad sobrevenida fortuita); tales razones afectan, como mucho, a las consecuencias de la reclamación y a posibles indemnizaciones a que dé lugar. Es necesario, por último, para poder resolver el contrato, haber dado cumplimiento de la respectiva obligación emanada del contrato. ${ }^{41}$

$38 \quad$ Cfr. Quicios (2009) p. 1337.

39 Díaz (2008) p. 1360; en la misma línea, Mayor Del Horo (2010) p. 106, "como consecuencia de dicha resolución, el contrato quedaría sin efectos al deshacerse el vínculo del mismo. La extinción se retrotrae al momento de la celebración del contrato, es decir, los efectos de la resolución operan ex tunc, de manera que las partes deberán, en su caso, restituirse recíprocamente las prestaciones efectuadas".

$40 \quad$ Cfr. KLEIN (1997) p. 45.

41 Cfr. Quicios (2009) p. 1346-1356. 
En cuanto a los efectos, resolución y desistimiento sí se asemejan, porque la resolución del contrato es constitutiva y no declarativa, al igual que el desistimiento, razón por la cual opera ex tunc, es decir con efectos retroactivos, lo que obliga a las partes a la restitución de las prestaciones recibidas. ${ }^{42}$ Ejemplo de lo dicho, lo encontramos en el artículo 74.1 del TRLGDCU, el cual lleva por título Consecuencias del Ejercicio del derecho de desistimiento, aclarando que: "ejercido el derecho de desistimiento, las partes deberán restituirse recíprocamente las prestaciones de acuerdo con lo dispuesto en los artículos 1.303 y 1.308 del CC".

La resolución, no obstante, tiene otra configuración jurídica, debido a que es un remedio otorgado por la ley cuando una de las partes incumple las obligaciones que le corresponde dentro de una relación contractual, mientras que el desistimiento se otorga al consumidor sólo en ciertos contratos, sin necesidad de alegar causa alguna (ad nutum).

Sin embargo, también existen otras diferencias: por ejemplo, la ley prohíbe al empresario imponer al consumidor cláusula penal por daños y perjuicios cuando éste decida ejercer su derecho de desistimiento (artículo 73 y 102.1 del TRLGDCU). En la figura de la resolución, la persona que incumple se encuentra obligada al pago de daños y perjuicios y, en su caso, al abono de intereses (artículo 1.124-2 del CC); e incluso, puede pactarse al respecto una cláusula penal, y hasta ponerle un precio a la facultad de resolución unilateral del contrato.

\section{II. ¿QUÉ ES EL DERECHO DE DESISTIMIENTO DEL CONSUMIDOR?}

Una vez que hemos visto los típicos supuestos de ineficacia contractual, regulados en el Código Civil, trataremos de responder a la pregunta: ¿Qué es el derecho de desistimiento del consumidor? Para ello describiremos sus características y analizaremos el concepto estipulado en el artículo 68.1 del TRLGDCU, pero antes analizaremos su régimen jurídico.

\section{El régimen jurídico del actual derecho de desistimiento en el ámbito de consumo}

En un principio la Ley $n^{\circ}$ 26/1984, General para la Defensa de los Consumidores y Usuarios (en adelante LGDCU) prohibía expresamente la facultad de desistir del contrato a cualquiera de las partes (artículo 10.1.c.2)

$42 \quad$ Cfr. Klein (1997) p. 47. 
salvo para ciertos casos: venta por correo a domicilio y por muestrario. ${ }^{43} \mathrm{En}$ este sentido, como afirmó Klein, la LGDCU "recogió un principio básico en nuestro derecho de obligaciones: la prohibición de dejar el contrato al arbitrio de uno de los contratantes. En defecto, admitir de forma general el pacto en condiciones generales de que el consumidor pueda extinguir la relación contractual ad nutum sería prácticamente como dar al artículo 1.256 del CC el carácter de norma dispositiva al menos en este concreto aspecto, y permitir que las partes alteren el principio de igualdad, al menos formal, de los contratantes". ${ }^{44}$

Durante la tramitación parlamentaria de la LGDCU y la discusión al artículo 10 en las Cortes Generales del Senado, en el Diario de Sesiones, publicado el miércoles 13 de junio de 1984, dentro de la enmienda número 93 realizada a dicho artículo, se incluyó a las ventas por muestrario dentro de la facultad de otorgar a una de las partes (consumidor), la posibilidad de resolver el contrato de manera discrecional. ${ }^{45}$

En aquel momento, el derecho de desistimiento del consumidor no estaba tan desarrollado como hoy en día en la Unión Europea (en adelante UE). Es importante mencionar, además, que España entró formalmente como Estado miembro de la UE en 1986. Por otra parte, es necesario aclarar que son diversos los contratos, en donde se le otorga el desistimiento al consumidor, la mayoría de los cuales tiene su propio régimen jurídico, entre los que encontramos los siguientes:

i) Contratos celebrados fuera de los establecimientos mercantiles. La Directiva 85/577/CEE, reguló en un principio el régimen jurídico de los contratos celebrados fuera de los establecimientos mercantiles. Sin embargo, la Directiva mencionada ha sido derogada por la actual DDC.

$43 \quad$ Vid. Artículo 10.1.c.2 de la LGDCU: “(...) Las cláusulas que otorguen a una de las partes la facultad de resolver discrecionalmente el contrato, excepto, en su caso, las reconocidas al comprador en las modalidades de venta por correo, a domicilio y por muestrario".

44 Klein (1997) p. 340; en la misma línea, Beluche (2009a) p. 41.

45 La enmienda comentada, según el Senador José María García Royo del Grupo Parlamentario Popular, se debe a que: "Puestos a enumerar las modalidades que permiten la resolución discrecional del contrato, no debe omitirse una que cada vez tiene mayor importancia, por la agresión permanente y psicológica de una clase de oferta por acercamiento como las aquí citadas" (Vid. Serie II: Textos Legislativos de 4 de junio de 1984, Congreso de los Diputados, Boletín Oficial de las Cortes Generales del Senado, Serie A, $\mathrm{n}^{\circ} 134$ c), p. 56. 
ii) Contratos a distancia. La transposición de la DDC unificó el derecho de desistimiento en los contratos a distancia (artículos 102 a 108 del TRLGDCU, modificados por la Ley $n^{\circ} 3 / 2014$ ).

iii) Contratos de servicios financieros. La Directiva 2002/65/CE, en su artículo 6.1 regula el derecho de desistimiento para este tipo de contratos. Esta norma ha sido adaptada al ordenamiento español mediante la Ley $\mathrm{n}^{\circ}$ 22/2007, cuyo artículo 10 atribuye al consumidor la facultad de desistir en un plazo de 14 días naturales.

iv) Contratos de crédito al consumo. En un principio la Directiva 87/102/ CEE, en su artículo 4.3 regulaba un periodo de reflexión de manera indirecta y no de forma expresa a favor del consumidor. ${ }^{46}$ Posteriormente, con la aprobación de la Directiva 2008/48/CE, el artículo 14 de tal norma ofrece la oportunidad al consumidor de desistir del contrato en un periodo de 14 días. Esta Directiva ha sido transpuesta al ordenamiento jurídico español a través de la Ley $n^{\circ} 16 / 2011$, la cual en su artículo 28 regula el derecho de desistimiento a favor del consumidor en un plazo de 14 días.

v) Contratos a plazo de bienes muebles. Con la adaptación de la Directiva 87/102/CEE, se expide la Ley n ${ }^{\circ} 28 / 1998$, la cual regula en su artículo 9.2 el derecho de desistimiento, no obstante tal derecho debe interpretarse acorde con el artículo 28 de la Ley ${ }^{\circ}$ 16/2011, pues, el derecho de desistimiento para este tipo de contratos se modificó, debido a la transposición de la Directiva 2008/48/CE.

vi) Contratos de aprovechamiento por turno. La Directiva 94/47/CE, regulaba en su artículo 5.1 el derecho de desistimiento; tal Directiva se transpuso al ordenamiento jurídico español mediante la Ley $n^{\circ} 42 / 1998$, la cual, en su artículo 10, previó el derecho de desistimiento a favor del consumidor. Sin embargo, tal ley ha sido derogada por la transposición de la Directiva 2008/122/CE, a través del Real Decreto-ley n 8/2012, el cual contempla a favor del consumidor un derecho de desistimiento en un periodo de 14 días naturales $y$, como novedad, contempla un formulario de desistimiento.

46 Esta norma se transpuso en un inicio al ordenamiento jurídico español mediante la Ley $\mathrm{n}^{\circ}$ 7/1995, de 23 de marzo. 


\section{El Concepto y las características del derecho de desistimiento del con- sumidor}

A continuación, veremos de manera general las características del derecho de desistimiento del consumidor, las cuales marcan la diferencia con otras formas de ineficacia contractual, como la anulabilidad, rescisión, resolución o la revocación, etc.

\section{A) SE TRATA DE UN DERECHO DISCRECIONAL}

El consumidor, al momento de ejercitar el desistimiento, no tiene porqué alegar causa ni motivo alguno, es decir, con su sola declaración de voluntad el contrato se extingue: así ocurre en los contratos a distancia ${ }^{47}$, de tiempo compartido y en los contratos celebrados fuera de establecimiento mercantil, entre otros. ${ }^{48}$ Es un derecho ad nutum, libre de toda condición (artículo 115 del CC), reconocido a una o ambas partes en una relación sinalagmática ${ }^{49}$,

$47 \quad$ Vid. Artículo 28.1 de la Ley no 16/2011: "El derecho de desistimiento de un contrato de crédito es la facultad del consumidor de dejar sin efecto el contrato celebrado (...) sin necesidad de indicar los motivos (...); artículo 14.1 de la Directiva 2008/48/CE, de crédito al consumo: "El consumidor dispondrá de un plazo de 14 días civiles para desistir del contrato de crédito sin indicar el motivo"; artículo 12.1 del Real Decreto-ley n 8/2012: "En los contratos regulados en este real decreto-ley, el consumidor tendrá derecho de desistimiento sin necesidad de justificación alguna"; artículo 6.1 Directiva 2008/122/CE: “(...) los Estados miembros velarán por que el consumidor pueda, en un plazo de catorce días naturales desistir del contrato (...) sin necesidad de justificación"; artículo 6.1 de la Directiva 2002/65/CE: "Los estados miembros velarán por que el consumidor disponga de un plazo de 14 días naturales para rescindir el contrato a distancia, sin indicación de los motivos"; artículo 10.1 de la Ley 22/2007: "El consumidor dispondrá de un plazo de catorce días naturales para desistir del contrato a distancia, sin indicación de los motivos (...)"

48 En la misma línea el artículo 6 de la Directiva 2002/65/CE señala: “Los estados miembros velarán por que el consumidor disponga de un plazo de 14 días naturales para rescindir el contrato a distancia, sin indicación de los motivos y sin penalización alguna (...)". Artículo 9 de la DDC: "Salvo en caso de aplicación de las excepciones establecidas en el artículo 16, el consumidor dispondrá de un periodo de 14 días para desistir de un contrato a distancia o celebrado fuera del establecimiento, sin indicar motivo y sin incurrir en ningún coste distinto de los previstos en el artículo 13, apartado 2, y en el artículo 14".

Vid. Exposición de Motivos del Real Decreto-ley n 8/2012 aclara: "El capítulo IV regula el desistimiento como un derecho de naturaleza única ad nutum, sin expresión de motivos; y ello, tanto si el empresario hubiera facilitado correctamente la información precontractual, como si la hubiere omitido o lo hubiera hecho de manera insuficiente. No se 
siendo necesario para que surta efectos su ejercicio, notificárselo a la parte con quien se desea terminar la relación contractual, para lo cual se aplicarán los criterios generales del CC (artículo 1.262, el cual establece las reglas de la perfección del contrato)..$^{50}$ Sin embargo, el desistimiento se debe adaptar al principio de buena fe y a la prohibición del abuso del derecho. ${ }^{51}$

Por otra parte, el artículo 85.4 del TRLGDCU considera abusivas: "las cláusulas que autoricen al empresario resolver anticipadamente un contrato de duración determinada, si al consumidor y usuario no se le reconoce la misma facultad, o las que le faculten a resolver los contratos de duración indefinida en un plazo desproporcionadamente breve o sin previa notificación con antelación razonable".

trata de dos derechos de naturaleza diferente, sino única; y solo varía en ambos supuestos el cómputo de los plazos de ejercicio del derecho. Con ello se asume el criterio de la Directiva del 2008 que en sus versiones francesa e inglesa utiliza los términos se retracter y withdraw, respectivamente. Y acaba con el dualismo de la Directiva de 1994 que utilizaba dichos términos para el desistimiento ad nutum, cuando el empresario facilitó correctamente la información; utilizando, sin embargo, para los supuestos de falta o incorrecta información precontractual los términos resiliasion y cancelation, en francés e inglés respectivamente. Con este tratamiento unitario se acaba con la confusión suscitada por la traducción española de la Directiva de 1994 que había utilizado la palabra 'resolución', lo que se trasladó a la Ley de 1998, que aplicó el sistema dual de 'desistimiento' para los casos de información correcta y «resolución» para los de falta o incorrecta información precontractual". Vid. Martín (2009) p. 97.

$51 \quad$ Vid. Miranda (2011) pp. 1513 y 1514: "El derecho de desistimiento se configura en el TRDCU como una facultad de ejercicio discrecional. Quiere así significarse que el consumidor no está obligado legalmente a motivar y justificar su decisión de desvinculación negocial. De ahí que este derecho se conciba por algunos como una facultad, para subrayar que puede ser ejercitado automáticamente sin necesidad de acudir a los tribunales, y que en caso de acudir a éstos, los jueces no están obligados a analizar los móviles que Ilevaron al consumidor a revocar su declaración de voluntad. Para otros, sin embargo, el derecho de desistimiento se presente como un derecho potestativo o de configuración jurídica (Gestaltungsrecht), con referencia a aquellos derechos que atribuyen a su titular (en la generalidad de los casos mediante una declaración de voluntad de carácter recepticio) la facultad de crear, modificar o extinguir una determinada relación jurídica. Ahora bien, una cosa es que el desistimiento sea un derecho ad nutum que, como tal, puede ser ejercitado sin necesidad de justificación alguna, y otra bien distinta que se trate de un derecho ilimitado. Como todo derecho, el de desistimiento encuentra sus límites en las exigencias de la buena fe y la prohibición del abuso del Derecho". 
También se considera cláusula abusiva por limitar los derechos básicos del consumidor: "la imposición de cualquier otra renuncia o limitación de los derechos del consumidor y usuario" (artículo 86.7 del TRLGDCU); y en concreto la retención de cantidades abonadas por el consumidor y usuario por renuncia, sin contemplar la indemnización por una cantidad equivalente si renuncia el empresario (artículo 87.2 del TRLGDCU). Además, el artículo 87.3 y 4 del TRLGDCU, prohíbe: "la autorización al empresario para resolver el contrato discrecionalmente, si al consumidor y usuario no se le reconoce la misma facultad" y "la posibilidad de que el empresario se quede con las cantidades abonadas en concepto de prestaciones aún no efectuadas cuando sea él mismo quien resuelva el contrato".

Finalmente, el artículo 87.6 declara como cláusula abusiva por falta de reciprocidad: "Las estipulaciones que impongan obstáculos onerosos o desproporcionados para el ejercicio de los derechos reconocidos al consumidor y usuario en el contrato, en particular en los contratos de prestación de servicios o suministro de productos de tracto sucesivo o continuado, la imposición de plazos de duración excesiva, la renuncia o el establecimiento de limitaciones que excluyan u obstaculicen el derecho del consumidor a poner fin a estos contratos (...)".

Es importante aclarar que la nulidad de alguna de las cláusulas anteriormente mencionadas pudiera llegar a provocar la ineficacia del contrato en una situación no equilibrada entre las partes, tal y como se señala en el artículo 83 del TRLGDCU, al aclarar: "Las cláusulas abusivas serán nulas de pleno derecho y se tendrán por no puestas. A estos efectos, el Juez, previa audiencia de las partes, declarará la nulidad de las cláusulas abusivas incluidas en el contrato, el cual, no obstante, seguirá siendo obligatorio para las partes en los mismos términos, siempre que pueda subsistir sin dichas cláusulas" ${ }^{52}$

52 Este artículo fue modificado por la Ley $\mathrm{n}^{\circ}$ 3/ 2014, tal y como se señala en la Exposición de Motivos Punto III: "En otro orden de cosas, la ley procede a dar cumplimiento a la sentencia de 14 de junio de 2012, en el asunto C-618 Banco Español de Crédito. El Tribunal de Justicia de la Unión Europea ha interpretado la Directiva 93/13/CE del Consejo, de 5 de abril de 1993, sobre las cláusulas abusivas en los contratos celebrados con consumidores, en lo que respecta al artículo 83 del texto refundido de la Ley General para la Defensa de los Consumidores y Usuarios y otras leyes complementarias, aprobado mediante Real Decreto Legislativo 1/2007, de 16 de noviembre. En concreto, el Tribunal entiende que España no ha adaptado correctamente su Derecho interno al artículo 6, apartado 1, de la Directiva 93/13/CEE. El incumplimiento que el Tribunal de Justicia estima que se ha producido en relación con el artículo 83 del texto refundido, obedece a la facultad que se atribuye al juez nacional de modificar el contenido de las cláusulas abusivas que figuran 
El consumidor puede ejercer su derecho de desistimiento sin alegar motivo alguno, es decir, por su propia voluntad (artículo 68.1 del TRLGDCU).

\section{B) IRRENUnCIABLE PARA EL CONSUMIDOR Y USUARIO}

El derecho de desistimiento es irrenunciable para el consumidor (artículo 10 del TRLGDCU) ${ }^{53}$, pues las leyes que lo otorgan tienen carácter imperativo, razón por la cual, el consumidor puede dejar sin efecto el contrato, aun cuando no se le haya informado sobre su derecho a desistir o se le haya intentado privar de dicho derecho contractualmente. ${ }^{54}$

en los contratos, para integrar la parte afectada por la nulidad con arreglo a lo dispuesto por el artículo 1258 del Código Civil y el principio de buena fe objetiva. El Tribunal considera que dicha facultad podría poner en peligro la consecución del objetivo a largo plazo previsto en el artículo 7 de la Directiva, pues contribuiría a eliminar el efecto disuasorio que ejerce sobre los profesionales el hecho de que, pura y simplemente, tales cláusulas abusivas no se apliquen a los consumidores, en la medida en que dichos profesionales podrían verse tentados a utilizar cláusulas abusivas al saber que, aun cuando llegara a declararse la nulidad de las mismas, el contrato podría ser integrado por el juez nacional en lo que fuera necesario, garantizando de este modo el interés de los empresarios. En función de ello, se modifica la redacción del citado artículo 83 del texto refundido, para la correcta transposición del artículo 6, apartado 1, de la Directiva 93/13/CEE, de 5 de abril de 1993".

53 Vid. Artículo 5.1 de la Ley $n^{\circ}$ 16/2011: "Ios consumidores no podrán renunciar a los derechos reconocidos en este Ley"; artículo 16.1 Real Decreto-ley n 8/2012: "los consumidores no podrán renunciar a los derechos que se les reconoce en este real decreto-ley"; artículo 3.1 de la Ley $n^{\circ}$ 22/2007: "Los consumidores de los servicios financieros prestados a distancia no podrán renunciar a los derechos que se le reconocen en esta ley".

"Los consumidores no podrán renunciar a los derechos que se les reconozca en virtud de la transposición al Derecho nacional de la presente Directiva" (art. 12.1 de la Directiva 97/7/CE); "cuando el comprador sea un consumidor, entendiendo por tal el definido en los apartados 2 y 3 del artículo 1 de la Ley 26/1984, de 19 de julio, General para la Defensa de los Consumidores y Usuarios, los derechos que el presente capítulo le reconoce serán irrenunciables y podrán ser ejercidos por los mismos aunque la legislación aplicable al contrato sea otra distinta de la española, si el contrato presenta un vínculo estrecho con el territorio de cualquier Estado miembro de la Unión Europea" (art. 48.1 de la Ley de Ordenación del Comercio Minorista, en adelante LOCM); "Ia renuncia previa a los derechos que esta norma reconoce a los consumidores y usuarios es nula, siendo, asimismo, nulos los actos realizados en fraude de ley de conformidad con lo previsto en el artículo 6 del Código Civil" (art. 10 del TRLGDCU); "Si la legislación aplicable al contrato es la de un Estado miembro, el consumidor no podrá renunciar a los derechos que le confieran las disposiciones nacionales de transposición de la presente Directiva. Toda disposición 


\section{C) SU EJERCICIO TIENE CARÁCTER TEMPORAL}

El TRLGDCU establece el plazo de 14 días naturales para que el consumidor emita su declaración de desistir (artículos 71.1 y 104$)^{55}$, los cuales se computan de acuerdo con lo previsto en el artículo 5 del CC. ${ }^{56}$ Los plazos otorgados por la ley en materia de desistimiento como más adelante tendremos ocasión de comprobar, son de caducidad.

Como se observa, el derecho de desistimiento como forma de ineficacia sobrevenida del contrato, puede ejercerse en un período delimitado de tiempo, a diferencia de la nulidad del contrato, la cual no prescribe y puede declararse de oficio, o la anulabilidad la cual prescribe en un periodo de cuatro años.

\section{D) LIBERTAD DE FORMA PARA SU EJERCICIO}

El TRLGDCU, y demás leyes que contemplan el derecho de desistimiento del consumidor, no exigen una determinada forma para que el consumidor ejerza su derecho de desistimiento). ${ }^{57}$ Sin embargo, la mayoría de la doctrina

contractual que excluya o limite directa o indirectamente los derechos conferidos por la presente Directiva no vinculará al consumidor" (art. 25 de la DDC).

55 Vid. DiAZ (2014) p. 288.

56 Vid. Arnau (2011) pp. 157-196.

$57 \quad$ Las leyes que le conceden al consumidor un derecho de desistimiento no exigen formalidad alguna para que éste pueda ejercerlo. Por ejemplo, el artículo 14.3.a de la Directiva 2008/48/CE aclara, "para que el desistimiento surta efecto, antes de que expire el plazo previsto en el apartado 1, notificárselo al prestamista (...) por medios que puedan ser probados de conformidad con la legislación nacional (...)"; artículo 28.2.a de la Ley n ${ }^{\circ}$ 16/2011, “(...) se considerará que se ha respetado el plazo si la notificación se ha enviado antes de la expiración del plazo, siempre que haya sido efectuada mediante documento en papel o cualquier otro soporte duradero a disposición del prestamista y accesible para él"; artículo 7.1 de la Directiva 2008/122/CE: "si el consumidor tiene intención de ejercer el derecho de desistimiento, notificará su decisión al comerciante, en papel o en cualquier otro soporte duradero, antes de que expire el plazo de desistimiento. El consumidor podrá utilizar el formulario normalizado de desistimiento recogido en el anexo $\mathrm{V}$ y facilitado por el comerciante de conformidad con el artículo 5, apartado 4. (...)"; artículo 12.4 del Real Decreto-ley ${ }^{\circ}$ 8/2012: "el consumidor notificará de forma fehaciente al empresario el desistimiento por escrito en papel u otro soporte duradero, pudiendo utilizar el formulario en el anexo V. La expedición o envío de la notificación deberá hacerse dentro del plazo legal y será eficaz cualquiera que sea la fecha de recepción por el empresario", aunque la Directiva 2002/65/CE, ni la Ley no 22/2007, lo digan expresamente, también 
coincide en que el consumidor debería dejar constancia al momento de ejercitar el derecho de desistimiento, pues existen medios como el teléfono, en donde es difícil dejar prueba de tal derecho. ${ }^{58}$

Cabe aclarar que en el ordenamiento jurídico español no existe una postura uniforme en cuanto al documento de desistimiento. Algunas veces impone la obligación de informar sobre su existencia en el contenido del contrato. ${ }^{59}$ Aunque en otras ocasiones exige de forma separada un documento de desistimiento. ${ }^{60}$ La documentación y forma del derecho de desistimiento ha sido uno de los dolores de cabeza a nivel comunitario y nacional ${ }^{61}$, ya que el

se extiende la libertad de forma para ejercer el ejercicio del derecho de desistimiento a este tipo de contratos, ello lo entendemos, debido a que el TRLGDCU se aplica supletoriamente a las leyes especiales que contemplan el derecho de desistimiento y quedaron fuera de su refundición.

58 Vid. Beluche (2009b).

59 Vid. art. 9 de la Ley $n^{\circ}$ 22/2007, art. 16 de la Ley $n^{\circ} 16 / 2011$ y artículos 60.2.h y 97.1.i del TRLGCU). El estudio realizado por la Universidad de Bielefeld, en Schulte-NöLKE et.al. (2008) pp. 501-580, en donde se hace el estudio de la transposición de la Directiva 97/7/CE. Los autores aclaran que a diferencia de la Directiva 85/577/CEE y la Directiva 2002/65/CE, las cuales contienen una regla postal, en lo relativo a como el consumidor puede ejercer su derecho en forma y tiempo, la Directiva 97/7/CE, no contiene previsión similar alguna. No obstante, algunos Estados miembros como Austria, Bélgica, Alemania, Italia y Eslovenia han establecido una regla de entrega (por ejemplo un formulario de desistimiento). Países como Chipre, Letonia, y el Reino Unido, establecen una regla postal, según la cual se considerará que se ha enviado la notificación del desistimiento, atendiendo a la fecha de envío en que se realizó, independientemente de que tal notificación llegue después al vendedor. De ahí en nuestra opinión que sea importante utilizar el correo certificado para evitar problemas de prueba. Vid. Art. 12 del Real Decreto-ley n8/2012, art. 97.1.i del TRLGDCU.

61 Vid. Domínguez (2011) p. 629, cuando señala: “Pero el art. 69.1 TR-LGDCU exige además que la información se realice 'por escrito en el documento contractual'. La SAP [sentencia de la Audiencia Provincial] Zamora 21-3-2006, en un caso sometido a la LCCFEM [Ley de contratos celebrados fuera de establecimiento mercantil], destaca que no es suficiente la simple referencia a la posibilidad de desistir sino que el documento contractual debe hacer referencia clara a este derecho, a sus requisitos y a las consecuencias de su ejercicio. En el supuesto de que se utilicen condiciones generales de la contratación, el art. 63.1 TRLGDCU, dispone que se debe entregar al consumidor 'copia o documento acreditativo con las condiciones esenciales de la operación, incluidas las condiciones generales de la contratación, aceptadas y firmadas por el consumidor y usuario, cuando éstas sean utilizadas en la contratación'. El art. 80.1 exige, además, concreción, claridad y sencillez en la redacción de las cláusulas, 'con posibilidad de comprensión directa, sin reenvíos 
Tribunal de Justicia de las Comunidades Europeas en diversas sentencias en materia de contratos celebrados fuera del establecimiento mercantil ha dejado claro que cuando el empresario incumpla con la obligación de informar al consumidor de su derecho de desistimiento, el plazo se prorroga indefinidamente $^{62}$, o incluso se ha establecido el criterio de que un tribunal nacional pueda declarar de oficio la nulidad del contrato.

En relación con lo anterior, debemos aclarar que el consumidor puede ejercer el derecho de desistimiento en cualquier forma admitida en Derecho. En todo caso, se considerará válidamente ejercitado mediante el envío del documento de desistimiento o mediante la devolución de los productos recibidos. ${ }^{63}$

a textos o documentos que no se faciliten previa o simultáneamente a la conclusión del contrato, y a los que, en todo caso, deberá hacerse referencia expresa en el documento contractual'",.

${ }^{62}$ Art. 10.1 de la Ley $n^{\circ} 22 / 2007$.

63 En la misma línea que el TRLGDCU por lo que se refiere a la libertad de forma para ejercer el derecho de desistimiento se manifiestan las siguientes normas: artículo 11.1 y 2 de la actual DDC; artículo 44.2 de la LOCM: "el ejercicio del derecho de desistimiento no estará sujeto a formalidad alguna, bastando que se acredite en cualquier forma admitida en derecho"; artículo 14.3.a de la Directiva 2008/48/CE: "para que el desistimiento surta efecto, antes de que expire el plazo previsto en el apartado 1, notificárselo al prestamista (...) por medios que puedan ser probados de conformidad con la legislación nacional $(. . .)^{\prime \prime}$; artículo 28.2.a de la Ley ${ }^{\circ}$ 16/2011: "Se considerará que se ha respetado el plazo si la notificación se ha enviado antes de la expiración del plazo, siempre que haya sido efectuada mediante documento en papel o cualquier otro soporte duradero a disposición del prestamista y accesible para él (...)"; artículo 7.1 de la Directiva 2008/122/CE: "si el consumidor tiene intención de ejercer el derecho de desistimiento, notificará su decisión al comerciante, en papel o en cualquier otro soporte duradero, antes de que expire el plazo de desistimiento. El consumidor podrá utilizar el formulario normalizado de desistimiento recogido en el anexo $\mathrm{V}$ y facilitado por el comerciante de conformidad con el artículo 5, apartado 4. (...)"; artículo 12.4 del Real Decreto-ley n 8/2012: "el consumidor notificará de forma fehaciente al empresario el desistimiento por escrito en papel u otro soporte duradero, pudiendo utilizar el formulario en el anexo $V$. La expedición o envío de la notificación deberá hacerse dentro del plazo legal y será eficaz cualquiera que sea la fecha de recepción por el empresario (...)".

Aunque ni la Directiva 2002/65/CE, ni la Ley n²2/2007, lo digan expresamente, también se extiende la libertad de forma para ejercer el ejercicio del derecho de desistimiento a este tipo de contratos. Ello lo entendemos, debido a que el TRLGDCU se aplica supletoriamente a las leyes especiales que contemplan el derecho de desistimiento y quedan fuera de su refundición. 
Con la introducción del formulario previsto en el artículo 97.1.i, para el caso de los contratos a distancia, según el modelo del Anexo B del TRLGDCU se pretende facilitar el ejercicio del derecho de desistimiento en materia de contratos a distancia y especialmente en materia de contratación electrónica. Sin embargo, cuando el empresario no se lo proporcione al consumidor, el plazo para desistir se amplía a un año (artículo 105.2 TRLGDCU). De esta manera, se configura una sanción al incumplimiento del empresario, recayendo en él la carga de la prueba (artículo 97.8 del TRLGDCU, modificado por la Ley $\left.n^{\circ} 3 / 2014\right)$.

Aunque cabe aclarar que el consumidor puede ejercitar el derecho de desistimiento por cualquier medio, es decir, no es necesario ejercerlo por medio del formulario, incluso aunque éste le haya sido correctamente facilitado. No obstante, por razones de seguridad jurídica debe quedar constancia de ello, pues, la carga de la prueba del ejercicio del derecho de desistimiento recaerá en el consumidor (artículos 72 y 106.4 del TRLGDCU). Evidentemente, el consumidor que utilice el formulario y siga las instrucciones para la devolución del producto preconstituye la prueba más firme del correcto ejercicio de su derecho frente a posteriores reclamaciones del empresario. El legislador, por lo tanto, trata de motivar no sólo al empresario, sino también al consumidor, facilitándole el ejercicio del derecho y la prueba del mismo, adoptándose la teoría de la expedición, matizada por la teoría de la recepción.

\section{E) ES UNA DECLARACIÓN DE VOLUNTAD RECEPTICIA}

Para que el desistimiento surta sus efectos, es necesario que el consumidor se lo haga saber a la otra parte, en este caso al empresario (artículo 68.1 del TRLGDCU). ${ }^{64}$ Aunque, surge la duda de determinar el momento en

${ }^{64}$ Lo anterior se refleja en las siguientes normas: Ley n²2/2007, artículo 10.3 "el consumidor que ejerza el derecho de desistimiento lo habrá de comunicar al proveedor en los términos previstos por el contrato (...)"; artículo 6.6 de la Directiva 2002/65/CE "cuando el consumidor ejerza su derecho de rescisión, lo notificará, antes de expirar el plazo correspondiente (...)"; artículo 14.3.a de la Directiva 2008/48/CE: "para que el desistimiento surta efecto, antes de que expire el plazo previsto en el apartado 1, (el consumidor deberá) notificárselo al prestamista (...)"; artículo 28.2 a) de la Ley no 16/2011: "el consumidor que ejerza el derecho de desistimiento tendrá las obligaciones siguientes: (...) comunicarlo al prestamista antes de que expire el plazo previsto en el apartado $1(\ldots)^{\prime \prime}$; artículo 7 de la Directiva 2008/122/CE: "si el consumidor tiene intención de ejercer el derecho de desistimiento, notificará su decisión al comerciante, en papel o en cualquier otro soporte duradero (...)"; artículo 12.4 Real Decreto-ley n 8/2012: "El consumidor notificará de forma fehaciente al empresario del desistimiento por escrito o en papel u otro soporte 
que se hace efectiva la declaración de voluntad: ¿cuándo se ejercita el derecho de desistimiento o cuando llega al conocimiento del empresario? En nuestra opinión, el ejercicio del derecho de desistimiento del consumidor surte efecto desde el momento en que el consumidor desiste del contrato, es decir, "dentro del plazo contemplado en el artículo 104 y en el artículo 105, cuando haya enviado la comunicación relativa al ejercicio del derecho de desistimiento antes de que finalice dicho plazo. Para determinar la observancia del plazo para desistir se tendrá en cuenta la fecha de expedición de la declaración de desistimiento" (artículo 106.2 del TRLGDCU, modificado por la Ley $\left.n^{\circ} 3 / 2014\right){ }^{65}$

En este contexto, recalcamos que es necesario que el consumidor deje prueba de haber ejercido su derecho de desistimiento, ya que a él le corresponde probar que desistió del contrato en tiempo y forma en caso de litigio (artículos 72 y 106.4 del TRLGDCU), pues en la práctica ha ocurrido que el consumidor ha comunicado su decisión de desistir del contrato por teléfono al vendedor; no obstante, después la empresa lo ha demandado por incumplimiento contractual al no pagar el producto.

\section{F) Sin PENALIZACión alguna PARA el CONSUMidor}

El ejercicio del derecho de desistimiento no implicará gasto alguno para el consumidor cuando éste decida ejercitarlo (artículo 68.1 del TRLGDCU). En la misma línea que el actual del TRLGDCU se ha expresado el Tribunal

duradero (...)". En el mismo sentido se expresa en cuanto a su carácter recepticio a nivel comunitario el artículo 11.1 de la DDC: "Antes de que venza el plazo de desistimiento, el consumidor comunicará al comerciante su decisión de desistir del contrato".

65 Vid. MiRAnda (2011) pp. 1514 y 1515: "Al ser una declaración de voluntad, le son aplicables los principios generales que nuestro ordenamiento jurídico establece en relación con este tipo de declaraciones: podrá ser revocada y se someterá a las reglas relativas a la capacidad del declarante y a los vicios del consentimiento (...) Su carácter recepticio se explica por el hecho de que para que surta efectos habrá de ser conocida por la otra parte, con independencia de que ello suceda con anterioridad o posterioridad al plazo en el cual el consumidor tiene la facultad de ejercitar el derecho de desistimiento (plazo o período de reflexión). Así se desprende de los arts. 71.4 y 101.1 del TRDCU, de los que cabe inferir que lo realmente relevante para la validez del ejercicio del derecho de desistimiento es que la declaración de voluntad en que se corporeíza dicho derecho se emita y expida dentro del período fijado legalmente y no en el momento en que el empresario o su representante conocen de ella". 
de Justicia de las Comunidades Europeas en alguna de sus sentencias. ${ }^{66}$ Sin embargo, los gastos de devolución, por regla general, corresponden al consumidor (artículo 108.1 del TRLGDCU, modificado por la Ley $\mathrm{n}^{\circ} 3 / 2014$; artículo 14.2 de la DDC).

Aunque, hay que distinguir propiamente los gastos derivados su ejercicio y los derivados de su ejecución, por ejemplo, los contratos a distancia, el consumidor tiene la obligación de pagar la parte proporcional del servicio ejecutado, esto con base en el principio de buena fe, ya que de lo contrario habría un enriquecimiento ilícito.

Por otra parte, en caso de que el empresario impidiera al consumidor ejercer su derecho de desistimiento, a través de prácticas ilícitas, tales como imponerle gastos o penalizaciones, las cláusulas mencionadas serian nulas (artículo 86 del TRLGDCU).

\section{C) SU EIERCICIO DETERMINA LA EXTINCIÓN DEL CONTRATO DE CONSUMO CONCERTADO}

Al igual que otras formas de ineficacia contractual, el ejercicio del derecho de desistimiento extingue el contrato $^{67}$, surgiendo obligaciones tanto para el vendedor como para el consumidor ${ }^{68}$, aplicándose analógicamente la restitución recíproca prevista en el CC (artículos 1.303 y 1.308) para el caso de la nulidad de los contratos.

66 Vid. Tribunal de Justicia de las Comunidades Europeas, Travel Vac SL contra Antelm Sanchis (1999, asunto C-423/97), pár. 60: “(...) se opone a que un contrato contenga una cláusula por la que se impone al consumidor el pago de una indemnización a tanto alzado por daños causados al comerciante por el único motivo de que aquél haya ejercido su derecho de renuncia".

${ }_{67}$ Vid, en este sentido, Arnau (2009) p. 558.

68 Así lo manifiestan las siguientes normas en materia de consumo: artículo 7 de la Directiva 2002/65/CE, el cual prevé los efectos del desistimiento en este tipo de contratos; artículo 7 de la Ley $n^{\circ} 2002 / 2007$, la cual regula los efectos del desistimiento tanto para el vendedor como el consumidor; artículo 14.3 a y b) de la Directiva 2008/48/CE; artículo 28.1 de la Ley $n^{\circ}$ 16/2011: "El derecho de desistimiento de un contrato de crédito es la facultad del consumidor de dejar sin efecto el contrato celebrado (...)"; artículo 8.1 de la Directiva 2008/122/CE: "el ejercicio del derecho de desistimiento por el consumidor pondrá fin a la obligación de las partes de llevar a cabo lo estipulado en el contrato"; artículo 12.5 del Real Decreto-ley $n^{\circ}$ 8/2012: "El ejercicio del derecho de desistimiento por el consumidor dejará sin efecto el contrato". 
En materia de contratación a distancia es importante aclarar que los efectos del desistimiento son retroactivos (exttunc), para el caso de los bienes. Sin embargo, para el caso de los servicios es ex nunc (artículo 74 del TRLGDCU; artículo 12 de la DDC).

Con la transposición de la DDC al ordenamiento jurídico español, se armonizan plenamente tanto las obligaciones del consumidor como del vendedor. Además, se introducen reglas específicas (artículos 106 a 108 del TRLGDCU, modificados por la Ley $\mathrm{n}^{\circ} 3 / 2014$ ): por ejemplo, el consumidor no asumirá ningún coste por la depreciación de los bienes, o la ejecución del servicio cuando el empresario haya incumplido con el deber de información acerca del derecho de desistimiento.

\section{H) Puede tener su origen tanto legal como contractualmente}

El derecho de desistimiento del consumidor encuentra su origen en las Directivas europeas de consumo que lo regulan, las cuales se adaptan a los ordenamientos jurídicos de los Estados miembros. Sin embargo, cuando el derecho de desistimiento no encuentre su fundamento en la ley, el empresario puede estipular una cláusula contractual, en donde se le conceda al consumidor el derecho a desistir del contrato.

El legislador español, con la refundición de leyes que realizó en el año 2007, configuró un régimen general de derecho de desistimiento en los artículos 68 a 79 del TRLGDCU, creando de paso un derecho contractual de desistimiento, lo que constituye una novedad legislativa en el ordenamiento jurídico español. ${ }^{69}$ Sin embargo, el desistimiento contractual, podría darse siempre y cuando no exista una regulación que lo prevea en una ley especial (o más allá de lo previsto por ésta), para lo cual se aplicará subsidiariamente las disposiciones del TRLGDCU, en materia de desistimiento, tal y como expresa el artículo 79, del mencionado texto: "A falta de previsiones específicas en la oferta, promoción, publicidad o en el propio contrato del derecho de desistimiento reconocido contractualmente, éste se ajustará a lo previsto en este Título".

Además, el desistimiento puede pactarse en cualquier tipo de contratos (incluidos los presenciales) a iniciativa del empresario, pasando a formar

69 Vid. artículo 68.2 del TRLGDCU ("Contenido y régimen del derecho de desistimiento"): "El consumidor tendrá derecho a desistir del contrato en los supuestos previstos legal o reglamentariamente y cuando así se le reconozca en la oferta, promoción, publicidad o en el propio contrato". 
parte de éstos, e, incluso en los casos en que esté legalmente previsto, siempre que se mejoren las condiciones reguladas por la ley. No obstante, el legislador español ha impuesto dos límites en materia de derecho de desistimiento contractual (artículo 79 del TRLGDCU): el primero es la prohibición de indemnizar al empresario por el desgaste o deterioro del bien y, el segundo, la prohibición del pago de anticipos del consumidor al empresario. En este sentido, Cavanillas Múgica refiriéndose al desistimiento no regulado por la ley, aclara que si el empresario otorga al consumidor el derecho a desistir del contrato en condiciones menos favorables, como sería la reducción del plazo de 14 días naturales o exigir anticipos, durante el periodo de desistimiento, no deben considerarse cláusulas abusivas, siempre y cuando no afecten a las limitaciones mencionadas. ${ }^{70}$

Por otra parte, debemos aclarar que antes de la entrada en vigor de la Ley $n^{\circ} 3 / 2014$, para una parte de la doctrina, el artículo 68 del TRLGDCU no desplazaba a la regulación del desistimiento que, con carácter general, se preveía en el artículo 10 de la LOCM, el cual regulaba ciertos aspectos de su ejercicio, como el plazo para ejercer el desistimiento, en caso de que en el contrato no se hubiere señalado. ${ }^{71}$ En cambio, para otro sector doctrinal, su ámbito de aplicación era discutible, poniendo de manifiesto sólo se aplicaba, a las compraventas a prueba y a las ventas de conformidad sometidas a condición suspensiva. ${ }^{72}$ Para un tercer grupo, las reglas contempladas en el artículo 10 de la LOCM, se aplicaban supletoriamente en caso de no existir previsión legal o contractual específica. ${ }^{73}$ Sin embargo, hoy en día, tal problemática se encuentra superada, ya que la Disposición final segunda de la Ley $n^{\circ}$ 3/ 2014, en su punto dos modifica la redacción del artículo que venimos comentando, quedando redactado de la siguiente forma: "Artículo 10. Derecho de desistimiento. Para el ejercicio del derecho de desistimiento se estará a lo dispuesto por el artículo 71 del texto refundido de la Ley General para la Defensa de los Consumidores y Usuarios y otras leyes complementarias, aprobado mediante Real Decreto Legislativo 1/2007, de 16 de noviembre". Además, el actual

70 Cfr. Cavanillas (2008) p. 2156; en la misma línea: DiéGuez (2009); Evangelio (2011) pp. 44-45.

71 Cfr. MARín et. al. (1996) p. 96: (...) "el precepto regula la indemnización que, en su caso, debe abonar el comprador por el ejercicio de tal derecho y el plazo de que, en efecto de previsión legal expresa o de pacto, dispone el comprador para desistir. El artículo 10, por tanto, no reconoce el derecho de desistimiento, sino que lo regula". En la misma línea: Álvarez (2009) p. 209 y Díaz (1997) p. 98, nota 16.

72 Vid. Bercovitz et. al. (1997), p. 714.

73 Cfr. García et. al. (2009) p. 1498. 
artículo 79 del TRLGDCU establece las reglas del derecho contractual de desistimiento.

\section{CONCLUSIONES}

El derecho de desistimiento del consumidor ha nacido como un instrumento más de la política legislativa en la Unión Europea con el fin de proteger al consumidor como parte débil. Aunque debemos señalar que es una forma de ineficacia contractual, al igual que otra figuras jurídicas (como la resolución, la rescisión, entre otras), sin embargo, se diferencia de las mencionadas al presentar los siguientes caracteres propios: su discrecionalidad, su irrenunciabilidad, la temporalidad para su ejercicio, la libertad de forma para ejercerlo, su carácter recepticio, no conlleva penalización alguna, su ejercicio determina la extinción del contrato de consumo concertado y puede tener su origen tanto legal como contractual.

De las características apuntadas podemos deducir el siguiente concepto de "derecho de desistimiento del consumidor": Es la facultad irrenunciable del consumidor y usuario de dejar sin efectos el contrato celebrado, notificándoselo a la otra parte contratante, en el plazo establecido, en cualquiera de las formas admitidas en Derecho, ya se encuentre previsto legal o contractualmente, sin necesidad de alegar causa alguna y sin penalización de ninguna clase, salvo las cargas impuestas por la ley, las cuales se justifican dependiendo de la modalidad contractual.

El concepto que nosotros proponemos tiene una gran utilidad práctica y teórica. En primer lugar, da seguridad a las empresas, que pueden concretar fácilmente el alcance de sus obligaciones para con el consumidor al respecto de dicho derecho. Desde el punto de vista teórico, subsana las deficiencias de las normativas europeas y nacional.

\section{BIBLIOGRAFÍA CITADA}

Álvarez, María (2000): El desistimiento unilateral en los contratos con condiciones generales (Madrid, Edersa).

Arnau, Lídia (2009): "El desistimiento contractual del consumidor en el futuro libro VI del Código Civil de Cataluña", en BosCh CAPDevila (dir.): Derecho contractual Europeo. Problemática, propuestas y perspectivas (Barcelona, Bosch) 549-562 pp. 
BECKER, Rainer y GARCíA, José (1996): "Ley alemana sobre revocación de negocios a domicilio y otros negocios análogos", Revista de Derecho Privado, no 80: pp. 913-921.

Beluche Rincón, Iris (2009a): El derecho de desistimiento de consumidor (Valencia, Tirant lo Blanch).

(2009b): "Algunas notas sobre el derecho del Consumidor a desistir del contrato", Diario la Ley, n 7182, Sección Tribuna, 26 de mayo, la Ley $11783 / 2009$.

BerCovitz, Rodrigo (1997): "Comentario a los artículos 38 a 48 de la LOCM", en Bercovitz, Rodrigo y Leguina, Jesús (coords): Comentarios a las leyes de ordenación del comercio minorista (Madrid, Tecnos) 663-736 pp.

CañIZARes, Ana (2001): La caducidad de los derechos y acciones (Madrid, Civitas).

Cavanillas, Antonio (2008): "El Real Decreto Legislativo 1/2007, por el que se aprueba el texto refundido de la Ley General para la Defensa de los Consumidores y usuarios y otras leyes complementarias", Aranzadi Civil, $\mathrm{n}^{\mathrm{o}}$ 1: pp. 2133-2166.

De Castro, Federico (2008): III Derecho Civil de España. El negocio jurídico y la persona jurídica (Pamplona, Civitas).

Díaz Alabart, Silvia (1997): "Comentario al artículo 10 de la LOCM", en Piñar Mañas, José, y Beltrán Sánchez (dirs.): Comentarios a la ley de ordenación de comercio minorista y a la ley orgánica complementaria (Madrid, Civitas) pp. 91-101.

(2014): Contratos a distancia y contratos fuera del establecimiento mercantil. Comentario a la Directiva 2011/83 (Adaptado a la Ley 3/2014, de modificación del TR LCU) (Madrid, Reus).

Díaz PARDO, Gloria (2008): "Extinción del contrato mediante la resolución y la rescisión: diferencias y semejanzas en su régimen jurídico", Actualidad Civil, nº 13: pp. 1345-1367.

Dízz-PıCAzo, Luis (2007): Fundamentos de Derecho Civil Patrimonial: Introducción teoría del contrato (6 ${ }^{a}$ edición, Navarra, Civitas). 
Dízz-PıCazo, Luis y Gullón, Antonio (2002): Il Sistema de Derecho Civil: El contrato en general (Madrid, Tecnos).

Domínguez Luelmo, Andrés (2011): "Comentarios a los artículos 68-79 del TRLGDCU", en Cámara Lapuente, Sergio (dir.): Comentarios a las normas de protección de los consumidores: Texto Refundido (RDL 1/2007) y otras leyes y reglamentos vigentes en España y en la Unión Europea (Madrid, Colex) pp. 475-695.

Evangelo, Raquel (2011): “¿Es abusiva la entrega de vales en la compraventa de productos de consumo? (Reflexiones en relación con el desistimiento unilateral del consumidor y la resolución del contrato)", Revista de Derecho Privado, nº 7-8: pp. 3-51.

García, Vicente (1997): Ley de contratos celebrados fuera de los establecimientos mercantiles: el derecho de revocación (Navarra, Aranzadi).

(2009): "Comentario a los artículos 68-79 del TRLGDCU", en BerCovitz, Rodrigo (coord.): Comentario al Texto Refundido de la Ley General para la Defensa de los Consumidores y Usuarios y otras leyes complementarias (Real Decreto Legislativo 1/2007) (Navarra, Aranzadi) pp. 845-882.

Grimalt, Pedro (2008): Ensayo sobre la nulidad del contrato en el Código Civil: Revisión crítica de la categoría de la anulabilidad (Granada, Comares).

JeREZ, Carmen (2011): La anulación del contrato (Navarra, Aranzadi).

KLEIN, Michele (1997): El desistimiento unilateral del contrato (Madrid, Civitas).

Lasarte, Carlos (2010): Principios de Derecho Civil III: Contratos (13 ${ }^{\text {a }}$ edición, Madrid, Marcial Pons).

MARíN LóPEZ, Juan (1996): "Comentario al artículo 10 de la Ley de Ordenación del Comercio Minorista", en Arimany, Manubens \& Asociados (coords.): Ordenación del comercio minorista, comentarios a la ley 7/1996 y a la ley orgánica 2/1996, ambas de fecha de 15 de enero (Barcelona, Praxis) pp. 91-100.

Márquez, José (2008): Teoría general de las nulidades (4ª edición, México D.F., Porrúa). 
MARTín, Sara (2009): “Los derechos potestativos en la Ley 22/2007: El derecho de desistimiento contractual", Perspectivas del sistema financiero, $\mathrm{n}^{\circ}$ 96: pp. 93-108.

Mayor Del Hoyo, María (2010): "Rescisión, resolución, revocación y desistimiento unilateral", en PARRA, María (coord.): Obligaciones y contratos, cuadernos II, eficacia e ineficacia del contrato (Madrid, Dykinson) pp. 101-132.

MiRANDA, Luis (2011): "Título III contratos celebrados a distancia", en Rebollo, Manuel e IzQuierdo, Manuel (dirs.): La Defensa de los Consumidores y Usuarios. Comentario sistemático del Texto Refundido aprobado por el Real Decreto Legislativo 1/2007 (Madrid, lustel) pp. 1563-1686.

Parra, María (1997): "Comentario a los artículos 8 a 12 LOCM", en Bercovitz, Rodrigo y Leguina, Jesús (coords.): Comentarios a la Ley del Comercio Minorista (Madrid, Tecnos) pp. 8-228.

Pasquau, Miguel (1997): Nulidad y anulabilidad del contrato (Madrid, Civitas).

Quicios, María (2009): "La ineficacia contractual", en BeRCovitz, Rodrigo (dir.): Tratado de contratos, tomo I (Valencia, Tirant lo Blanch) pp. 1215-1399.

Rodrí́cuez, Concepción (1991): El desistimiento unilateral (como causa de extinción del contrato) (Madrid, Montecorvo).

Schulte-Nölke, Hans, Twigg-Flesner, Christian, Ebers y Martin (eds.) (2008): EC Consumer Law Compendium. Comparative Aanalysis (Universitat Bielefeld, Muchen) pp. 501-580.

\section{NORMAS JURÍDICAS CITADAS}

Código Civil de España. Real Decreto de 24 de julio de 1889 por el que se publica el Código Civil. Boletín Oficial del Estado n 206, de 25 de julio de 1889. Texto consolidado con última modificación de 6 de octubre de 2015.

Directiva 85/577/CEE del Consejo, referente a la protección de los consumidores en el caso de contratos negociados fuera de los establecimientos comerciales, de 20 de diciembre de 1985. 
Directiva 87/102/CEE del Consejo, relativa a la aproximación de las disposiciones legales, reglamentarias y administrativas de los Estados miembros en materia de crédito al consumo, de 22 de diciembre de 1986.

Directiva 94/47/CE del Parlamento Europeo y del Consejo, relativa a la protección de los adquirentes en lo relativo a determinados aspectos de los contratos de adquisición de un derecho de utilización de inmuebles en régimen de tiempo compartido, de 26 de octubre de 1994.

Directiva 97/7/CE del Parlamento Europeo y del Consejo, relativa a la protección de los consumidores en materia de contratos a distancia, de 20 de mayo de 1997.

Directiva 2002/65/CE del Parlamento Europeo y del Consejo, relativa a la comercialización a distancia de servicios financieros destinados a los consumidores, y por la que se modifican la Directiva 90/619/CEE del Consejo y las Directivas 97/7/CE y 98/27/CE, de 23 de septiembre de 2002.

Directiva 2008/48/CE del Parlamento Europeo y del Consejo, relativa a los contratos de crédito al consumo y por la que se deroga la Directiva 87/102/CEE del Consejo, de 23 de abril de 2008.

Directiva 2008/122/CE del Parlamento Europeo y el Consejo, relativa a la protección de los consumidores con respecto a determinados aspectos de los contratos de aprovechamiento por turno de bienes de uso turístico, de adquisición de productos vacacionales de larga duración, de reventa y de intercambio, de 14 de enero de 2009.

Ley $n^{\circ} 3 / 2014$, por la que se modifica el Texto Refundido de la Ley General para la Defensa de los Consumidores y Usuarios y otras leyes complementarias, aprobado por el Real Decreto Legislativo 1/2007, de 16 de noviembre, Boletín Oficial del Estado n 76, de 28 de marzo de 2014.

Ley $\mathrm{n}^{\circ}$ 7/1995, sobre crédito al consumo, de 23 de marzo de 1995.

Ley n ${ }^{\circ}$ 16/2011, de contratos de crédito al consumo, de 24 de junio de 2011.

Ley $n^{\circ} 22 / 2007$, sobre comercialización a distancia de servicios financieros destinados a los consumidores, de 11 de julio de 2007.

Ley ${ }^{\circ}$ 26/1984, General para la Defensa de los Consumidores y Usuarios, de 19 de julio de 1984. 
Ley $n^{\circ} 26 / 1991$, de contratos celebrados fuera de establecimientos mercantiles, de 26 de noviembre de 1991.

Ley $n^{\circ} 42 / 1998$, sobre derechos de aprovechamiento por turno de bienes inmuebles de uso turístico y normas tributarias, de 15 de diciembre de 1998, vigente hasta el 18 de marzo de 2012.

Real Decreto-ley $n^{\circ}$ 8/2012, de contratos de aprovechamientos por turno, de contratos de aprovechamiento por turno de bienes de uso turístico, de adquisición de productos vacacionales de larga duración, de reventa y de intercambio, de 16 de marzo de 2012.

Texto Refundido de la Ley General para la Defensa de los Consumidores y Usuarios y otras leyes complementarias, Real Decreto Legislativo $\mathrm{n}^{\circ}$ 1/2007, de 16 de noviembre de 2007.

\section{JURISPRUDENCIA CITADA}

Tribunal de Justicia de las Comunidades Europeas, Shearson Lehmann Hutton Inc. contra TVB Treuhandgesellschaft für Vermögensverwaltung und Beteiligungen $\mathrm{mbH}$ (1993): 19 enero 1993, asunto C-89/91. Disponible en: <http://eur-lex.europa.eu/resource.html?uri=cellar:ce34d16f-d531461b-9a02-eda796e7bc78.0008.06/DOC_2\&format=PDF>, fecha de consulta: 29 de octubre de 2014.

Benincasa contra Dentalkit SRL (1997): 3 de julio de 1997, asunto C-269/95. Disponible en: <http://eur-lex.europa.eu/legal-content/ES/ TXT/PDF/?uri=CELEX:61995CJ0269\&rid=1>, fecha de consulta: 29 de octubre de 2014.

, Travel Vac SL contra Antelm Sanchis (1999): 22 abril 1999, asunto C-423/97. Disponible en: <http://eur-lex.europa.eu/legal-content/ES/ TXT/PDF/?uri=CELEX:61997CJ0423\&rid=8>, fecha de consulta: 29 de octubre de 2014.

, Engler contra Janus Versand GmbH (2005): 20 enero 2005, asunto C-27/02. Disponible en: <http://eur-lex.europa.eu/legal-content/ES/TXT/ PDF/?uri= CELEX:62002CJ0027\&rid=1>, fecha de consulta: 29 de octubre de 2014.

Gruber contra Bay Wa AG (2005): 20 de enero de 2005, asunto C-464/01. Disponible en: <http://eur-lex.europa.eu/legal-content/ES/TXT/PDF/?uri= 
SOSA OLÁN, HENRRY (2016): EL DERECHO DE DESISTIMIENTO DEL CONSUMIDOR EN EL ORDENAMIENTO JURÍDICO ESPAÑOL. SU DELIMITACIÓN RESPECTO DE OTRAS FORMAS DE INEFICACIA CONTRACTUAL

CELEX:62001CJ0464\&qid=1414637219424\&fr om=ES>, fecha de consulta: 29 de octubre de 2014. 